Jurnal Ekonomi Modernisasi

http://ejournal.unikama.ac.id/index.php/JEKO

JEM Vol : 12 No. 1, pp : 13-22

\title{
DETERMINAN KEPUASAN PEDAGANG SEBAGAI NASABAH BRI
}

\author{
Inayah Ayu Agung \\ S2 Sains Ekonomi Islam, Sekolah Pasca Sarjana, Universitas Airlangga \\ Jl. Airlangga No. 4-6 Surabaya, Indonesia
}

\begin{abstract}
This study analyzes the factors that affect customer satisfaction. Customers will be satisfied if the bank is able to deliver the quality expected. The quality of service, price, product, promotion and the location is an important factor supporting the performance of BRI for the better. The purpose of this study was to analyze the influence of service, price, product, promotion, and location to the satisfaction of merchants who are customers of BRI Branch Unit Kemlagi Mojokerto. The independent variables consist of service, price, product, promotion, and location. The dependent variable is satisfaction. Using multiple regression analysis. Samples taken as many as 28 customers using quota sampling. Data collection techniques by distributing a questionnaire using Likert scale. The results showed that simultaneous service, price, product, promotion, and location of positive and significant impact on satisfaction. Partially service, price, product, promotion, and location of positive and significant impact on satisfaction. Variable service, price, product, promotion and location can be a determinant of customer satisfaction BRI.
\end{abstract}

Keywords: Services, Pricing, Product, Promotion, Location, Satisfaction

DOI : http://dx.doi.org/10.21067/jem.v12i1.1173

Diterima : Nopember 2015; Direvisi: Januari 2016; Diterima : Februari 2016

\section{PENDAHULUAN}

Bank adalah lembaga keuangan penghimpun dana dalam bentuk simpanan kemudian disalurkan pada masyarakat. Penyaluran bank tidak semata-mata berusaha untuk memperoleh keuntungan tetapi juga untuk peningkatan taraf hidup masyarakat. Bank Rakyat Indonesia (BRI) adalah salah satu bank milik pemerintah terbesar di Indonesia.

* Corresponding Author.

E-mail: inayah.agung@ymail.com
Pada periode setelah kemerdekaan RI, berdasarkan Peraturan Pemerintah No. 1 tahun 1946 Pasal 1 disebutkan bahwa BRI adalah sebagai Bank Pemerintah pertama di Republik Indonesia.

Nasabah merupakan aset penting dalam meningkatkan eksistensi bank. Kepercayaan nasabah merupakan modal utama memperlancar kegiatan oprasional. Semakin banyak nasabah yang mempercayakan uangnya untuk dikelola bank semakin banyak pula dana yang disalurkan sehingga peluang mendapatkan keuntungan semakin luas. Semakin banyak jumlah bank maka persaingan antar bank untuk mendapatkan nasabah semankin kuat. Bank membutuhkan 
strategi untuk menjaring nasabah sebanyakbanyaknya. Strategi pemasaran yang tepat menjadi hal yang sangat penting menarik kepercayaan nasabah. Selanjutnya yang perlu diperhatikan bank adalah bagaimana bank dapat memberikan kepuasan pada nasabah. Tidak hanya memperoleh kepercayaan tetapi juga kepuasan merupakan cara mempertahankan nasabah. Bank harus mampu menjawab tantangan memenuhi kebutuhan dan keinginan nasabah, ekspektasi nasabah yang demikian menjadi tolak ukur kepuasan.

Sebuah produk atau layanan perbankan dikatakan mempunyai nilai yang tinggi di mata nasabah apabila mampu memberikan kualitas, manfaat dan pengorbanan yang seminimal mungkin (Hidayat, 2009). Kualitas pelayanan merupakan tingkat keunggulan yang diharapkan dan pengendalian atas tingkat keunggulan tersebut untuk memenuhi keinginan konsumen. Cara untuk mempertahankan konsumen adalah memberikan jasa dengan kualitas pelayanan yang lebih tinggi dari pesaing secara konsisten dan memenuhi harapan pelanggan. Kualitas pelayanan yang baik akan meningkatkan kepuasan konsumen. Sebaliknya kualitas pelayanan yang buruk akan menurunkan kepuasan konsumen (Gulla dkk, 2015).

Setiap cash flow yang dikelola bank melalui kesetiaan nasabah, jika perusahaan memberikan pertimbangan pada nasabah yang setia pada saat menetapkan harga akan membantu menciptakan kepuasan nasabah (Niharika, 2015). Harga memiliki manfaat yang besar terhadap tingkat kepuasan konsumen karena dengan harga yang terjangkau maka konsumen akan puas. Penetapan harga yang tidak sesuai akan menurunkan kepuasan konsumen. (Gulla dkk, 2015).

Jika perusahaan menghasilkan berbagai produk berdasarkan kebutuhan nasabah, maka nasabah dapat memperoleh kebebasan untuk memilih dari banyak pilihan produk (Ahmed \& Rahman, 2015). Bank yang menyediakan berbagai macam produk sesuai kebutuhan nasabah berarti berusaha memenuhi keinginan nasabah kemudian nasabah akan merasa puas jika produk-produk bank yang diinginkan dapat terpenuhi.

Promosi merupakan salah satu aspek penting dalam manajemen karena promosi dapat menimbulkan rangkaian kegiatan selanjutnya dari perusahaan. Ahli-ahli ekonomi menekankan adanya faedah atau kegunaan waktu, tempat, bentuk dan milik dalam pemasaran. Suatu barang akan berguna apabila pemakai dapat dengan mudah mendapatkannya pada waktu yang tepat serta tempat yang mudah diakses. Tingkat kepuasan pelanggan dapat dinilai dari kesesuaian ekspektasi pelanggan pasca promosi (Putra, 2010 dalam Haryanto, 2013).

Saluran distribusi sangat penting untuk mempertahankan kepuasan pelanggan karena merupakan sarana yang menghubungkan produk dan jasa dari produsen ke pelanggan (Ahmed \& Rahman, 2015). Lokasi bank merupakan sarana yang menghubungkan produk dan jasa bank pada nasabah untuk memberikan kepuasan.

Kepuasan nasabah merupakan hal penting dalam kesuksesan pemasaran, mendukung keberhasilan menguasai pangsa pasar dan menunjukkan kemampuan bersaing antar bank. Kepuasan nasabah memberikan manfaat yang dapat menarik nasabah baru secara tidak langsung melalui promosi mulut ke mulut dan mendorong loyalitas nasabah. Kepuasan nasabah perlu dijaga dengan memahami perilaku nasabah. Bank perlu membangun komunikasi dengan nasabah untuk mengetahui persepsi nasabah terkait pemasaran. Bank yang menerima banyak persepsi nasabah dapat mengetahui hasil kinerja bank yang perlu dievaluasi dan kinerja bank yang perlu ditingkatkan untuk menjaga kepuasan.

Tujuan penelitian ini untuk menganalisis secara simultan pengaruh pelayanan, harga, produk, promosi, dan lokasi terhadap kepuasan dan untuk mengetahui secara parsial pengaruh pelayanan, harga, produk, promosi, dan lokasi terhadap kepuasan pedagang yang merupakan nasabah BRI Cabang Mojokerto Unit Kemlagi. Manfaat dilakukan penelitian adalah: berkontribusi memberikan gambaran terkait 
variabel-variabel yang mempengaruhi kepuasan nasabah dan dapat dijadikan refrensi untuk penelitian lebih lanjut.

\section{TINJAUAN PUSTAKA Pelayanan}

Pelayanan adalah semua kegiatan atau manfaat yang dapat ditawarkan suatu pihak lain, yang pada dasarnya tidak berwujud dan tidak menghasilkan kepemilikan sesuatu (Kotler \& Amstrong 2008).

Bank sebagai penyedia jasa memberikan pelayanan pada nasabah. Pelayanan menjadi aspek penting kualitas jasa dalam memberikan kenyamanan dan perhatian pada nasabah. Pengabaian pelayanan dari waktu-kewaktu bisa berdampak pada kehilangan nasabah.

Hasil temuan penelitian Mulyono, dkk (2007), (Hidayat, 2009), Sriwidodo \& Indriastuti (2010), Endarwita (2013), Gunawan (2013), Haryanto (2013), Zain (2013), Ismail (2014), Khan (2014), Gulla, dkk (2015) dan Wijayaningratri \& Budiyanto (2015) menunjukkan bahwa pelayanan berpengaruh signifikan terhadap kepuasan.

\section{Harga}

Harga merupakan sejumlah uang yang ditagihkan atas suatu produk atau jasa, atau jumlah dari nilai yang ditukarkan para pelanggan untuk memperoleh manfaat dari memiliki atau menggunakan suatu produk atau jasa (Kotler \& Armstrong, 2008).

Bank dapat menetapkan harga yang menarik untuk simpanan dana pihak ketiga. Bank juga dapat menetapkan biaya yang rendah untuk menarik minat nasabah peminjam. Harga yang rendah untuk setoran awal bagi penabung dapat memudahkan bank bersaing memperoleh banyak nasabah. Nasabah dapat merasa lebih puas dengan penetapan harga rendah dibandingkan dengan harga yang lebih tinggi pada saat pembukaan rekening karena dapat menjangkau kalangan masyarakat berpenghasilan rendah yang ingin memiliki rekening bank. Semakin banyak nasabah yang menyimpan dananya di bank semakin banyak kesempatan bank untuk mengembangkan dana dan memperoleh income. Agar dana yang dimiliki bank bisa berkembang perlu adanya upaya untuk menyalurkan. Strategi penetapan biaya yang rendah pada nasabah peminjam dapat membantu meringankan beban nasabah dalam mengembangkan bisnisnya sehingga nasabah mampu melakukan pembayaran hutang pada bank.

Hasil temuan penelitian Bailia, dkk (2014), Gulla dkk (2015) dan Hermawan (2015) menunjukkan bahwa harga berpengaruh signifikan terhadap kepuasan. Sedangkan temuan Johannes, dkk. (2009) dan Taher (2013) menunjukkan bahwa harga tidak berpengaruh signifikan terhadap kepuasan.

\section{Produk}

Kualitas produk merupakan karakteristik produk atau jasa yang bergantung pada kemampuannya untuk memuaskan kebutuhan pelanggan yang dinyatakan atau diimplikasikan (Kotler \& Armstrong, 2008). Dari aspek pemasaran jasa, produk merupakan keseluruan konsep obyek atau proses yang memberikan sejumlah nilai kepada konsumen (Lupiyoadi dan Hamdani, 2006 dalam Endarwita, 2013).

Intensitas kompetisi di pasar memaksa perusahaan untuk mengupayakan adaptasi produk yang tinggi guna meraih keunggulan yang kompetitif atas pesaing, karena adaptasi produk dapat memperluas basis pasar lokal dan ditingkatkan untuk preferensi lokal tertentu. Konsumen semakin banyak memiliki alternatif dan sangat hati-hati dalam menentukan keputusan untuk melakukan pembelian dengan mempertimbangkan faktor-faktor kebutuhan, keunggulan produk, pelayanan dan perbandingan harga sebelum memutuskan untuk membeli. Dari faktor-faktor tersebut, keunggulan produk termasuk ke dalam pertimbangan utama sebelum membeli. Keunggulan kompetitif suatu produk merupakan salah satu faktor penentu dari kesuksesan produk baru, dimana kesuksesan produk tersebut diukur dengan parameter jumlah penjualan produk. (Tjiptono, 2008).

Tujuan menciptakan produk-produk bank adalah untuk menarik minat nasabah. Produk dikatakan sebagai produk yang 
berkualitas apabila produk yang dihasilkan bank mampu memberikan kepuasan bagi nasabah. Beberapa produk yang dihasilkan bank bisa berupa produk simpanan, pemberian kridit maupun jasa-jasa yang lain. Beragam pilihan produk yang disajikan akan dapat membantu nasabah dalam menentukan pilihan yang sesuai.

Hasil temuan penelitian Mulyono, dkk (2007), (Hidayat, 2009), Johannes, dkk. (2009), Endarwita (2013), Haryanto (2013), Bailia, dkk (2014), Ismail (2014), dan Hermawan (2015) menunjukkan bahwa produk berpengaruh signifikan terhadap kepuasan. Sedangkan temuan Taher (2013) menunjukkan bahwa produk tidak berpengaruh signifikan terhadap kepuasan.

\section{Promosi}

Promosi adalah suatu bentuk komunikasi pemasaran yang merupakan aktivitas pemasaran yang berusaha menyebarkan informasi, mempengaruhi/membujuk, dan/atau meningatkan pasar sasaran atas perusahaan dan produknya agar bersedia menerima, membeli, dan loyal pada produk yang ditawarkan perusahaan yang bersangkutan. (Tjiptono, 2007).

Promosi merupakan suatu ungkapan dalam arti luas tentang kegiatan-kegiatan yang secara efektif dilakukan perusahaan untuk mendorong konsumen menggunakan produk atau jasa yang ditawarkan (Gulla dkk, 2015).

Promosi sebagai bentuk strategi bank untuk mencapai tujuan, diperlukan inovasi yang kreatif agar pesan yang ingin disampaikan pada nasabah dan calon nasabah dapat tersampai dan mendapatkan respon yang baik.

Hasil temuan penelitian Johannes, dkk. (2009), Lumintang (2013), Taher (2013), Zain (2013), dan Setiawan (2014) menunjukkan bahwa promosi berpengaruh signifikan terhadap kepuasan. Sedangkan temuan Haryanto (2013) dan Gulla, dkk (2015) menunjukkan bahwa promosi tidak berpengaruh signifikan terhadap kepuasan.

\section{Lokasi}

Lokasi sebagai kegiatan pemasaran yang berusaha memperlancar dan mempermudah penyampaian barang dan jasa dari produsen ke konsumen, sehingga penggunanya sesuai dengan yang diperlukan. Pengukuran variabel ini yaitu ketersediaan ruangan, dapat dicapai dengan mudah, dan pengunjung/calon pembeli (Gunawan, 2013).

Kemudahan nasabah menjangkau tempat untuk melakukan transaksi perlu diperhatikan untuk memberi kepuasan. Biasanya berupa penyediaan layanan atm, kantor pusat, kantor cabang, cabang pembantu, kantor kas, dan lain sebagainya.

Hasil temuan penelitian Johannes, dkk. (2009), Bailia, dkk (2014), dan Wijayaningratri \& Budiyanto (2015) menunjukkan bahwa lokasi berpengaruh signifikan terhadap kepuasan. Sedangkan temuan Gunawan (2013) dan Taher (2013), menunjukkan bahwa lokasi tidak berpengaruh signifikan terhadap kepuasan.

\section{Kepuasan}

Kepuasan nasabah menyangkut apa yang diungkapkan oleh nasabah tentang persepsi dan harapannya terhadap layanan perbankan yang diperoleh dari bank (Hidayat, 2009). Kepuasan nasabah dapat diartikan sebagai kesesuaian antara apa yang dirasakan oleh nasabah dari pengalamannya menggunakan jasa sebuah bank dengan apa yang diharapkannya dari bank tersebut. (Wijayaningraratri \& Budiyanto, 2015).

Kinerja karyawan dalam memberikan layanan akan menentukan apakah jasa yang dihasilkan dapat memenuhi harapan nasabah. (Sriwidodo, 2010). Pada industri perbankan, kualitas pelayananan merupakan salah satu aspek yang paling penting dari pengalaman yang diperoleh nasabah. Sebagian besar organisasi memantau kualitas layanan mereka secara teratur untuk menjamin, meningkatkan kepuasan nasabah dan mempertahankan loyalitas nasabah. Kepuasan nasabah diperoleh dengan memenuhi permintaan dan harapan terkait penyediaan layanan sampai pada standar pasar. (Gitomer, 1998 dalam Khan, 2014). 
Jurnal Ekonomi Modernisasi, Vol : 12 No. 1, pp : 13-22

Keadaan nasabah yang didominasi pedagang dan tingkat pendidikan SMU sederajat merupakan informasi awal yang dapat dijadikan pengelolaan kepuasan nasabah prioritas. Bahwa nasabah tidak puas terhadap biaya (penalti) yang dikenakan dan harus dijadikan titik penting dalam komunikasi pemasaran (Johannes dkk, 2009). Kepuasan nasabah sebagai salah satu tujuan utama perusahaan untuk mendapatkan loyalitas nasabah yang akan menguntungkan perusahaan dalam jangka panjang. Sehubungan dengan penetapan harga yang dibebankan, nasabah tidak hanya menginginkan harga yang lebih murah namun mereka juga menginginkan nilai dari produk atau pelayanan yang sama sesuai dengan harapan mereka (Ahmed \& Rahman, 2015).

Nasabah adalah penilai kualitas suatu produk perbankan. Banyak ukuran yang bisa dipakai nasabah dalam menentukan kualitas suatu produk perbankan namun tujuan akhir yang dicapai adalah sama yaitu mampu memberikan rasa puas kepada nasabah. Semakin puas seorang nasabah dalam mengkonsumsi suatu produk perbankan maka dapat dikatakan semakin berkualitas produk perbankan. Puas atau tidak puasnya seorang nasabah ditentukan oleh kesesuaian harapan nasabah dengan persepsi nasabah pada kinerja aktual produk tersebut. (Hidayat, 2009).

Pomosi merupakan kegiatan yang bersifat mempengaruhi nasabah agar tertarik membeli produk yang dipasarkan oleh bank. Berbagai kebutuhan promosi yang paling berhasil adalah ketika perusahaan mempromosikan produk barang atau jasa yang memberi kepuasan bagi konsumen. (Lumintang, 2013).

Ketidaknyamanan nasabah menyebabkan ketidakpuasan nasabah yang selanjutnya dapat mempengaruhi organisasi secara negatif, untuk menjaga kenyamanan nasabah dengan memberi produk di tempat yang lebih sesuai dengan keinginan nasabah sehingga menciptakan kepuasan di antara nasabah. (Niharika, 2015)

\section{METODE}

Populasi dalam penelitian ini adalah seluruh nasabah BRI Unit Kemlagi Cabang Mojokerto yang berprofesi sebagai pedagang yang berlokasi di pasar Kemlagi. Sampel yang diambil sebanyak 28 nasabah dengan menggunakan quota sampling.

Variabel bebas dalam penelitian ini meliputi pelayanan, harga, produk, promosi, dan lokasi. Sedangkan variabel terikatnya adalah kepuasan. Sumber data berasal dari data primer, teknik pengumpulan data dengan melakukan penyebaran angket pada sejumlah nasabah BRI.

Teknik menilai jawaban dari pertanyaan menggunakan skala likert. Jenis data yang digunakan berupa data kuantitatif berupa data ordinal. Teknik analisis data yang digunakan untuk mengetahui pengaruh variabel pelayanan, harga, produk, promosi dan lokasi terhadap kepuasan baik secara simultan maupun parsial menggunakan regresi linier berganda.

Model penelitian seperti pada gambar 1 , terlihat bahwa kepuasan nasabah dipengaruhi 5 faktor yaitu pelayanan, harga, produk, promosi dan lokasi. Model persamaan regresi berganda dirumuskan ebagai berikut.

$Y=\beta_{1} X_{1}+\beta_{2} X_{2}+\beta_{3} X_{3}+\beta_{4} X_{4}+\beta_{5} X_{5}+e$

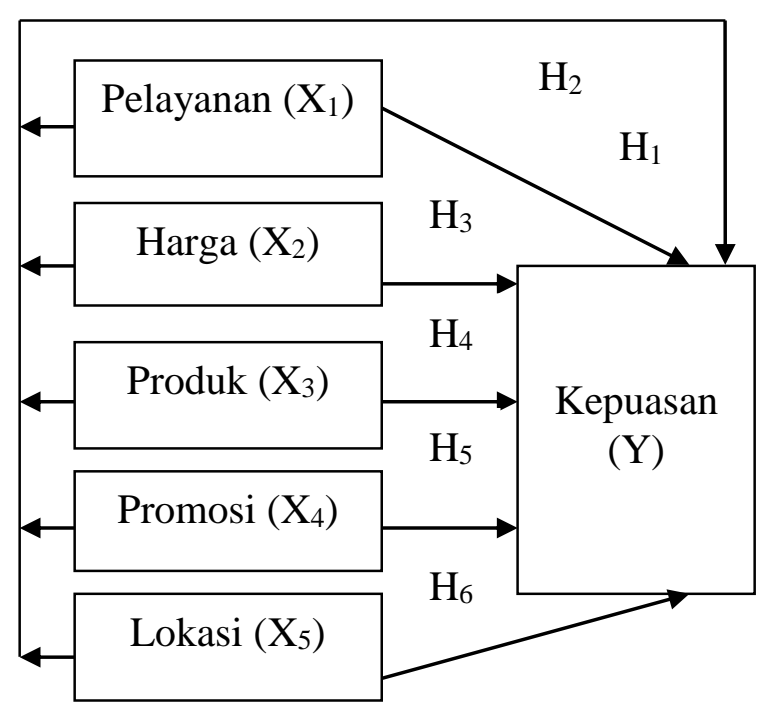

Gambar 1. Model Penelitian 


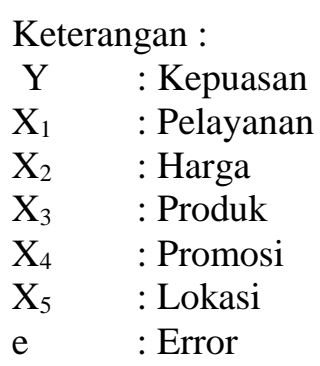

HASIL

Uji Koefisien Determinan dan Korelasi

Tabel 1.

Uji R dan R Square

\begin{tabular}{ccc}
\hline $\mathrm{R}$ & $\mathrm{R}$ Square & Durbin-Watson \\
\hline 0,870 & 0,759 & 1,357 \\
\hline
\end{tabular}

Predictors: (Constant), Lokasi, Promosi,

Pelayanan, Produk, Harga.

Dependent Variable: Kepuasan

Data Diolah, 2016

Berdasarkan pada tabel 1 hasil nilai korelasi atau $\mathrm{R}$ sebesar 0,870 hal ini menunjukkan bahwa pelayanan, harga, produk, promosi dan lokasi mempunyai pengaruh positif sebesar $87 \%$. Hasil nilai koefisien determinasi $\mathrm{R}^{2}$ sebesar 0,757. Menunjukkan bahwa variabel bebas meliputi pelayanan, harga, produk, promosi dan lokasi mampu menjelaskan varian kepuasan sebesar 75, 7\% sedangkan sisanya $24,3 \%$ dijelaskan oleh variabel lain diluar model.

\section{Uji F}

Tabel 2.

Uji F

\begin{tabular}{lccc}
\hline \multicolumn{1}{c}{ Model } & Df & F & Signifikansi \\
\hline Regression & 5 & 13,713 & 0,000 \\
\hline Residual & 22 & & \\
\hline Total & 27 & & \\
\hline Predictors: & (Constant), Lokasi, & Promosi, \\
Pelayanan, Produk, Harga & \\
Dependent Variable: Kepuasan
\end{tabular}

Data Diolah, 2016
Berdasarkan pada tabel 2 nilai $\mathrm{F}$ hitung sebesar 13,713 lebih besar dari $\mathrm{F}$ tablel 2,558 dan nilai probabilitas 0,000 lebih kecil dari 0,05. Sehingga pelayanan, harga, produk, promosi dan lokasi secara simultan berpengaruh positif dan signifikan terhadap kepuasan nasabah

\section{Uji t}

Tabel 3.

Uji t

\begin{tabular}{|c|c|c|c|}
\hline Item & $\begin{array}{l}\text { Unstanda } \\
\text { rsized } \\
\text { Coefficints } \\
\text { B }\end{array}$ & $\mathrm{t}$ & $\underset{n \text { Signifika }}{\text { Signifi }}$ \\
\hline Constant & -5345 & $-2,260$ & 0,034 \\
\hline $\begin{array}{l}\text { Pelayanan } \\
\text { (X1) }\end{array}$ & 0,237 & 3,269 & 0,004 \\
\hline $\begin{array}{l}\text { Harga } \\
(\mathrm{X} 2)\end{array}$ & 0,260 & 4,286 & 0,000 \\
\hline $\begin{array}{l}\text { Produk } \\
\text { (X3) }\end{array}$ & 0,306 & 2,525 & 0,019 \\
\hline $\begin{array}{l}\text { Promosi } \\
\text { (X4) }\end{array}$ & 0,314 & 3,237 & 0,004 \\
\hline Lokasi & 0,352 & 4,098 & 0,000 \\
\hline
\end{tabular}

(X5)

Dependent Variable: Kepuasan

Data Diolah, 2016

Berdasarkan pada tabel 3 untuk menguji $t$ dapat diketahui bahwa variabel bebas pelayanan, harga, produk, promosi dan lokasi secara parsial berpengaruh positif dan signifikan. Sehingga persamaan regresinya adalah:

$$
\begin{aligned}
Y= & -5,345+0,237 X_{1}+0,260 X_{2}+0,306 X_{3} \\
& +0,314 X_{4}+0,352 X_{5}
\end{aligned}
$$

Konstanta sebesar -5,345 mempunyai arti bahwa variabel pelayanan, harga, produk, promosi, dan lokasi jika bernilai tetap maka kepuasan nasabah menurun 5,345. Apabila pelayanan terhadap kepuasan ditingkatkan 1 satuan maka kepuasan akan meningkat sebesar 0,237 dengan syarat variabel harga, produk, promosi dan lokasi konstan. Apabila harga terhadap kepuasan ditingkatkan 1 satuan maka 
Jurnal Ekonomi Modernisasi, Vol : 12 No. 1, pp : 13-22

kepuasan akan meningkat sebesar 0,260 dengan syarat variabel pelayanan, produk, promosi dan lokasi konstan.

Apabila produk terhadap kepuasan ditingkatkan 1 satuan maka kepuasan akan meningkat sebesar 0,306 dengan syarat pelayanan, harga, promosi dan lokasi konstan. Apabila promosi terhadap kepuasan ditingkatkan 1 satuan maka kepuasan akan meningkat 0,314 dengan syarat pelayanan, harga, produk dan lokasi konstan. Apabila lokasi terhadap kepuasan ditingkatkan 1 satuan maka kepuasan akan mingkat 0,352 dengan syarat pelayanan, harga, produk dan promosi konstan.

\section{PEMBAHASAN}

\section{Pengaruh Pelayanan terhadap Kepuasan}

Menggunakan tingkat signifikansi 0,05 dan didapatkan output diperoleh t hitung sebesar 3,269 dan tabel distribusi t dicari pada $a=5 \%$ (Uji 2 sisi) dengan derajat kebebasan $\mathrm{df}=22$, dengan pengujian 2 sisi (signifikansi 2,048). Hasil penelitian menunjukkan bahwa nilai $\mathrm{t}$ hitung 3,269 lebih besar dari nilai t tabel 2,048 sehingga pelayanan mempunyai pengaruh positif sedangkan nilai probabilitas variabel pelayanan sebesar 0,004 lebih kecil dari 0,05 sehingga mempunyai nilai signifikan. Dapat diambil kesimpulan bahwa $\mathrm{H}_{2}$ diterima dan tolak $\mathrm{H}_{0}$ variabel pelayanan yang diberikan BRI mempunyai pengaruh positif dan signifikan terhadap kepuasan nasabah. Apabila BRI memberikan kualitas pelayanan yang semakin baik maka tingkat kepuasan nasabah akan semakin tinggi sebaliknya jika kualitas pelayanan yang diberikan BRI kurang baik maka tingkat kepuasan nasabah akan menurun.

Penelitian ini didukung oleh penelitian terdahulu Mulyono, dkk (2007), (Hidayat, 2009), (Sriwidodo \& Indriastuti, 2010), Endarwita (2013), Gunawan (2013), Ismail (2014), Khan (2014), Zain (2013) dan Wijayaningratri \& Budiyanto (2015), Haryanto (2013), dan Gulla, dkk (2015), menunjukkan bahwa pelayanan berpengaruh positif dan signifikan terhadap kepuasan.

\section{Pengaruh Harga terhadap Kepuasan}

Menggunakan tingkat signifikansi 0,05 dan didapatkan output diperoleh $t$ hitung sebesar 4,286 dan tabel distribusi t dicari pada $a=5 \%$ (Uji 2 sisi) dengan derajat kebebasan $\mathrm{df}=22$, dengan pengujian 2 sisi (signifikansi 2,048). Hasil penelitian menunjukkan bahwa nilai $\mathrm{t}$ hitung 4,286 lebih besar dari nilai $\mathrm{t}$ tabel 2,048 sehingga harga mempunyai pengaruh positif sedangkan nilai probabilitas variabel harga sebesar 0,000 lebih kecil dari 0,05 sehingga mempunyai nilai signifikan. Dapat diambil kesimpulan bahwa $\mathrm{H}_{3}$ diterima dan tolak $\mathrm{H}_{0}$ variabel harga yang ditawarkan BRI mempunyai pengaruh positif dan signifikan terhadap kepuasan nasabah. Apabila BRI memberikan harga yang kompetitif baik dari segi penabung maupun peminjam maka tingkat kepuasan nasabah akan semakin tinggi sebaliknya jika harga yang ditawarkan BRI kurang kompetitif maka tingkat kepuasan nasabah akan semakin menurun.

Hasil penelitian ini didukung penelitian terdahulu Bailia, dkk (2014), Hermawan (2015), dan Gulla, dkk (2015) menunjukkan bahwa harga berpengaruh positif dan signifikan terhadap kepuasan.

\section{Pengaruh Produk Terhadap Kepuasan}

Menggunakan tingkat signifikansi 0,05 dan didapatkan output diperoleh $t$ hitung sebesar 2,525 dan tabel distribusi t dicari pada $a=5 \%$ (Uji 2 sisi) dengan derajat kebebasan $\mathrm{df}=22$, dengan pengujian 2 sisi (signifikansi 2,048). Hasil penelitian menunjukkan bahwa nilai $\mathrm{t}$ hitung 2,525 lebih besar dari nilai t tabel 2,048 sehingga produk mempunyai pengaruh positif sedangkan nilai probabilitas variabel produk sebesar 0,019 kurang dari dari 0,05 sehingga bernilai signifikan. Dapat diambil kesimpulan bahwa $\mathrm{H}_{4}$ diterima dan tolak $\mathrm{H}_{0}$ variabel produk yang ditawarkan BRI berpengaruh positif dan signifikan terhadap nasabah. Apabila BRI menawarkan produk yang berkualitas maka tingkat kepuasan nasabah akan semakin tinggi sebaliknya jika produk yang ditawarkan BRI kurang berkualitas maka tingkat kepuasan nasabah akan semakin menurun. 
Hasil penelitian ini didukung penelitian terdahulu Mulyono, dkk (2007), (Hidayat, 2009), Johannes, dkk. (2009), Endarwita (2013), Haryanto (2013), Bailia, dkk (2014), Ismail (2014), dan Hermawan (2015) menunjukkan bahwa produk berpengaruh positif dan signifikan terhadap kepuasan.

\section{Pengaruh Promosi Terhadap Kepuasan}

Menggunakan tingkat signifikansi 0,05 dan didapatkan output diperoleh $t$ hitung sebesar 3,237 dan tabel distribusi t dicari pada $\mathrm{a}=5 \%$ (Uji 2 sisi) dengan derajat kebebasan $\mathrm{df}=22$, dengan pengujian 2 sisi (signifikansi 2,048). Hasil penelitian menunjukkan bahwa nilai $\mathrm{t}$ hitung 3,237 lebih besar dari nilai t tabel 2,048 sehingga promosi mempunyai pengaruh positif sedangkan nilai probabilitas variabel promosi sebesar 0,004 lebih kecil dari 0,05 sehingga mempunyai nilai signifikan. Dapat diambil kesimpulan bahwa $\mathrm{H}_{5}$ diterima dan tolak $\mathrm{H}_{0}$ variabel promosi yang ditawarkan BRI mempunyai pengaruh positif dan signifikan terhadap kepuasan nasabah. Apabila promosi BRI semakin baik maka tingkat kepuasan nasabah akan semakin tinggi sebaliknya jika promosi BRI kurang baik maka tingkat kepuasan nasabah akan semakin menurun.

Hasil penelitian ini didukung penelitian terdahulu Johannes, dkk. (2009), Taher (2013), dan Zain (2013) menunjukkan bahwa promosi berpengaruh signifikan terhadap kepuasan.

\section{Pengaruh Lokasi terhadap Kepuasan}

Menggunakan tingkat signifikansi 0,05 dan didapatkan output diperoleh t hitung sebesar 4,098 dan tabel distribusi t dicari pada $\mathrm{a}=5 \%$ (Uji 2 sisi) dengan derajat kebebasan $\mathrm{df}=22$, dengan pengujian 2 sisi (signifikansi 2,048). Hasil penelitian menunjukkan bahwa nilai $\mathrm{t}$ hitung 4,098 lebih besar dari nilai t tabel 2,048 sehingga lokasi mempunyai pengaruh positif sedangkan nilai probabilitas variabel lokasi sebesar 0,000 lebih kecil dari 0,05 sehingga mempunyai nilai signifikan. Dapat diambil kesimpulan bahwa $\mathrm{H}_{6}$ diterima dan tolak $\mathrm{H}_{0}$ variabel lokasi BRI mempunyai pengaruh positif dan signifikan terhadap kepuasan nasabah. Apabila lokasi BRI strategis maka tingkat kepuasan nasabah akan semakin tinggi sebaliknya jika lokasi BRI kurang strategis maka tingkat kepuasan nasabah akan semakin menurun.

Hasil penelitian ini didukung penelitian terdahulu Johannes, dkk. (2009), Bailia, dkk (2014), dan Wijayaningratri \& Budiyanto (2015) menunjukkan bahwa lokasi berpengaruh signifikan terhadap kepuasan.

Pengaruh Pelayanan, Harga, Produk, Promosi, dan Lokasi Terhadap Kepuasan

Menggunakan tingkat signifikansi 0,05 dan didapatkan output diperoleh $\mathrm{F}$ hitung sebesar 13,713 dan tabel distribusi $F$ dicari pada $\mathrm{n}=28$ dengan derajat kebebasan $\mathrm{df}=5$ diperoleh $(2,558)$. Hasil penelitian menunjukkan bahwa nilai $F$ hitung 13,713 lebih besar dari nilai $F$ tabel 2,558 sehingga pelayanan, harga, produk, promosi dan lokasi mempunyai pengaruh positif sedangkan nilai probabilitas $\mathrm{F}$ sebesar 0,000 kurang dari dari 0,05 sehingga bernilai signifikan. Dapat diambil kesimpulan bahwa $\mathrm{H}_{1}$ diterima dan tolak $\mathrm{H}_{0}$ variabel pelayanan, harga, produk, promosi dan lokasi secara simultan berpengaruh positif dan signifikan terhadap kepuasan nasabah.

\section{SIMPULAN DAN SARAN Simpulan}

Hasil penelitian tentang kepuasan nasabah BRI menunjukkan bahwa faktor-faktor yang terdiri dari variabel pelayanan, harga, produk, promosi dan lokasi secara simultan berpengaruh positif dan signifikan terhadap kepuasan. Variabel pelayanan, harga, produk, promosi dan lokasi secara parsial berpengaruh positif dan signifikan terhadap kepuasan. Hasil menunjukkan bahwa variabel pelayanan, harga, produk, promosi dan lokasi dapat menjadi determinan kepuasan pedagang sebagai nasabah BRI. 
Jurnal Ekonomi Modernisasi, Vol : 12 No. 1, pp : 13-22

Saran

Sampel data terkait kepuasan nasabah dimungkinkan adanya bias karena adanya keterbatasan waktu, sehingga hanya sebagian kecil pedagang yang merupakan nasabah BRI Unit Kemlagi dijadikan obyek penelitian. Hal ini disebabkan karena banyaknya pedagang yang juga nasabah BRI menyebar dibeberapa lokasi di Kecamatan Kemlagi. Penelitian ini juga terbatas pada variabel pelayanan, harga, produk, promosi dan lokasi untuk mengetahui faktor yang mempengaruhi kepuasan. Untuk penelitian lebih lanjut dapat dilakukan dengan menambahkan variabel-variabel terkait kepuasan.

\section{DAFTAR PUSTAKA}

Ahmed, S. \& Rahman, Md.H. (2015). The Effects of Marketing Mix on Consumer Satisfaction: A Literature Review from Islamic Perspectives. Turkish Journal of Islamic Economics, 2(1), 17-30.

Bailia, J.F.T., Soegoto, A.S. \& Loindong, S.S.R. (2014). Pengaruh Produk, Harga dan Lokasi terhadap Kepuasan Konsumen pada Warung-Warung Makan Lamongan di Kota Manado. Jurnal EMBA, 2(3), 1768-1780.

Endarwita. (2013). Pengaruh Kualitas Produk dan Kualitas Pelayanan terhadap Kepuasan dan Loyalitas Nasabah Tabungan Bank BRI Cabang Simpang Empat. E-Jurnal Apresiasi Ekonomi, 1(3), 167-180.

Gunawan, W.T. (2013). Bauran Pemasaran dan Kualitas Pelayanan Pengaruhnya terhadap Kepuasan Pelanggan pada Texas Chicken Manado. Jurnal EMBA, 1(4), 2049-2058.

Gulla, R., Oroh, S.G. \& Roring, F. (2015). Analisis Harga, Promosi, dan Kualitas Pelayanan terhadap Kepuasan Konsumen pada Hotel Manado Grace INN. Jurnal EMBA, 3(1), 1313-1322.

Hidayat, R. (2009). Pengaruh Kualitas Layanan, Kualitas Produk dan Nilai Nasabah terhadap Kepuasan dan Loyalitas
Nasabah Bank Mandiri. Jurnal Manajemen dan Kewirausahaan, 11(2), 59-72.

Haryanto, R.A. (2013). Strategi Promosi, Kualitas Produk, Kualitas Layanan terhadap Pelanggan pada Restoran MCDonald's Manado. Jurnal EMBA, 1(4), 1465-1473.

Hermawan, H. (2015). Analisis Pengaruh Bauran Pemasaran terhadap Keputusan, Kepuasan dan Loyalitas Konsumen dalam Pembelian Roti Ceria di Jember. Jurnal Manajemen dan Bisnis Indonesia, 1(2), 143-161.

Ismail, R. (2014). Pengaruh Kualitas Layanan, Kualitas Produk dan Kepuasan Nasabah Sebagai Prediktor dalam Meningkatkan Loyalitas Nasabah. Jurnal Organisasi dan Manajemen, 10(2), 176-196.

Johannes., Raf, M. \& Lukman, M. (2009). Analisis Kepuasan Nasabah Prioritas Berdasarkan Bauran Pemasaran (Kasus pada PT. Bank Central Asia Tbk Kantor Cabang Utama Jambi). Jurnal Manajemen Pemasaran Modern, 1(1), 35-45.

Kusumawati, A. (2011). Analisis Pengaruh Experiential Marketing terhadap Kepuasan dan Loyalitas Pelanggan: Kasus Hypermart Malang Town Square (Matos). Jurnal Manajemen Pemasaran Modern, 3(1), 75-86.

Khan, M.M. (2014). Impact of Service Quality on Customer Satisfaction and Customer Loyalty: Evidence from Banking Sector. Pakistan Journal of Commerce and Social Sciences, 8(2), 331-354.

Mulyono, B.H., Yoestini., Nugraheni, R. \& Kamal, M. (2007). Analisis Pengaruh Kualitas Produk dan Kualitas Layanan terhadap Kepuasan Konsumen (Studi Kasus pada Perumahan Puri Mediterania Semarang). Jurnal Studi Manajemen \& Organisasi, 4(2), 91-100.

Niharika. (2015). Effect of Marketing Mix on Customer Satisfaction. International Journal of Science, Technology \& Management, 4(1), 73-81. 
Sriwidodo, U. \& Indriastuti. (2010). Pengaruh Dimensi Kualitas Pelayanan Jasa terhadap Kepuasan Nasabah. Jurnal Ekonomi dan Kewirausahaan, 10(2), 164-173.

Tjiptono, F. (2007). Manajemen Penjualan Produk. Yogyakarta: Kanisius.

Tjiptono, F. (2008). Strategi Pemasaran 3th ed. Yogyakarta: Andy.

Taher, T.H. (2013). Pengaruh Bauran Pemasaran terhadap Kepuasan Layanan Jasa Pendidikan di Sekolah Tinggi Ilmu Ekonomi (STIE) Palangkaraya. Jurnal Sains Manajemen, 2(2), 1-11.

Kotler, P. \& Amstrong. G. (2008). PrinsipPrinsip Pemasaran 12th ed. Jakarta: Erlangga.

Lumintang, M.C. (2013). Promosi dan Customer Relationship Management Pengaruhnya terhadap Kepuasan Nasabah pada PT Bank Tabungan Negara (PERSERO) Cabang Manado. Jurnal EMBA, 1(4), 133-1041.

Wijayaningratri, C.S. \& Budiyanto. (2015). Pengaruh Fasilitas, Lokasi, dan Pelayanan terhadap Kepuasan Nasabah Bank Mega Syariah Walikukun. Jurnal Ilmu dan Riset Manajemen, 4(4), 1-16.

Zain, T. (2013). Pengaruh Kualitas Layanan dan

Promosi terhadap Kepuasan dan Loyalitas Pelanggan Speedy Instan. Jurnal Ekonomi Akuntansi dan Manajemen, 12(1), 104:114. 